\title{
God, or the Body without Organs
}

\author{
Steven Shaviro \\ shaviro@shaviro.com
}

God is the most perplexing figure in Whitehead's metaphysics. Who is he, what does he want, and what is he doing in Process and Reality? Whitehead's thought is entirely about process and transformation; it values becoming over being, relation over substance, and continual novelty over the perpetuation of the same. It rejects the "bifurcation of nature" (1920/2004, 30-31), or the separation of reality from appearance $(1929 / 1978,72)$. It holds that there is nothing besides "the experiences of subjects" (167); and it grants to all subjects - including inhuman and nonsentient ones - and to all their experiences - conscious or not - the same ontological status. Such a thought has no room for a specially "eminent" entity: one that would be absolute, unchanging, transcendent, and supersensible, as God is usually taken to be. Given Whitehead's rejection of traditional metaphysics and theology, why does God remain such a "stubborn fact" throughout Process and Reality? What role does this God play in Whitehead's cosmological system? ${ }^{1}$

Evidently, the God described by Whitehead bears little resemblance to the God of Christianity, or any other organized religion. Indeed, Whitehead is repulsed by the "Greek, Hebrew, and Christian" picture of "a static God condescending to the world" from transcendent heights (347). He deplores the way that "the vicious

\footnotetext{
${ }^{1}$ For the purposes of this chapter, I deliberately ignore the extensive literature on "process theology." Instead, I approach Whitehead's notion of God from an insistently nontheological perspective. That is to say, I seek to situate Whitehead in relation to the radical critique of transcendence that runs through Spinoza, Nietzsche, and Deleuze: a critique that is also, in a certain manner, one of the major stakes in Kant's transcendental argument, and in William James' "radical empiricism." From this point of view, it is tempting to follow Donald Sherburne's (1986) effort to excise God altogether from Whitehead's vision, the better to affirm a "neo-Whiteheadian naturalism" (83). But I think that God is too insistently present throughout the text of Process and Reality for this to be a viable option. I seek instead to develop a non-religious, or atheological, understanding of Whitehead's God.
} 
separation of the flux from the permanence leads to the concept of an entirely static God, with eminent reality, in relation to an entirely fluent world, with deficient reality" (346). He rejects what he wryly calls the "unfortunate habit... of paying [God] metaphysical compliments" (1925/1967, 179). He protests against the traditional adulation of God as a figure of might: the "worship of glory arising from power is not only dangerous; it arises from a barbaric conception of God" $(1926 / 1996,55)$. And he denounces "the doctrine of an aboriginal, eminently real, transcendent creator, at whose fiat the world came into being, and whose imposed will it obeys," as a pernicious "fallacy which has infused tragedy" into the history of the world $(1929 / 1978,342)$. For he judges that, despite the ethical content of Jesus' own teachings, through most of European history "the Gospel of love was turned into a Gospel of fear. The Christian world was composed of terrified populations" $(1926 / 1996,75) .^{2}$

Whitehead rejects the more refined philosophical notions of God as much as he does the "barbaric," popular or traditional ones. For instance, despite his own affinity with Leibniz, Whitehead dismisses "the Leibnizian theory of the "best of possible worlds" " as "an audacious fudge produced in order to save the face of a Creator constructed by contemporary, and antecedent, theologians" (1929/1978, 47). Leibniz's God selects among "an infinite number of possible universes," choosing the one that is the best. He bases his choice upon these worlds' different degrees of perfection: "each possible world [has] the right to claim existence in proportion to the perfection which it involves" (Leibniz 1973, 187). Perfection, however, has already been defined by Leibniz as "magnitude of positive reality" (185). So God chooses the world that is already, in itself, the most real. But Whitehead does not accept the Leibnizian notion of different degrees of reality. There is no ontological preeminence. The world, as "merely 'given'... does not disclose any peculiar character of 'perfection'" (Whitehead 1929/1978, 47). For "no reason, internal to history, can be assigned why that flux of forms, rather than

\footnotetext{
${ }^{2}$ The exemption of Jesus' ethical teachings from an otherwise thoroughgoing rejection of Christianity is a frequent theme in modern antireligious thought. Even Nietzsche often takes this position. Whitehead has little interest in Nietzsche; in fact, he claims never to have read The Antichrist (Price 2001, 131). Nonetheless, Whitehead, like Nietzsche, puts the blame for all that is bad in historical Christianity upon St. Paul. Whitehead describes Paul as the man who "did more than anybody else to distort and subvert Christ's teaching" (303); and he says that Paul's "idea of God, to my mind, is the idea of the devil" (186). He explicitly prefers John to Paul (1926/1996, 76). All this is worth recalling at a time when such thinkers as Badiou (2003) and Žižek (2003) have cited Paul as an exemplary revolutionary figure. As I discuss further below, Whitehead rejects the sort of universalism that Badiou and Žižek champion, and attribute to Paul.
} 
another flux, should have been illustrated" (46). The world is not predetermined, but radically contingent, because it is open to the immanent "decision" of each actual entity. God cannot have the power to decide for all these entities. Hence no "possible universe" can be judged a priori to be more perfect, or more intrinsically real, than any other. If God is held to be omnipotent, and given the credit for everything good that happens, "then the evil in the world is in conformity with the nature of God" as well (1926/1996, 95).

Whitehead's rejection of the Leibnizian God is entirely in accord with Kant's demonstration, in the "Transcendental Dialectic" of the First Critique, of the fallacies of speculative theology. Kant distinguishes three philosophical endeavors to prove the existence of God: the ontological, cosmological, and physiotheological proofs $(1996,577)$. But Kant rejects all of these alleged proofs, because in all of them, "a regulative principle is transformed into a constitutive one" (599). That is to say, these ostensible proofs take relations and determinations that are valid for entities within the world, and illegitimately apply them in order to explain the "thoroughgoing determination" of the world itself as a whole and in the first place (563). They then go on to hypostasize this principle of determination in the form of a supreme "being of all beings" (569). All such attempts to prove the existence of God thus make the mistake of applying empirical principles to establish something that is supersensible and non-empirical. This can never work, because "if the empirically valid law of causality is to lead to the original being, then this being would likewise have to belong to the chain of objects of experience; but in that case this being would itself, like all appearances, be conditioned in turn" (613).

Whitehead's own discussions of theology largely follow Kant's logic. Thus Whitehead dismisses the "ontological proof" of God's existence, because "any proof which commences with the consideration of the character of the actual world cannot rise above the actuality of this world... In other words, it may discover an immanent God, but not a God wholly transcendent" (1926/1996, 71). And he rejects the "cosmological argument," on the grounds that "our notion of causation concerns the relations of states of things within the actual world, and can only be illegitimately extended to a transcendent derivation" (1929/1978, 93). ${ }^{3}$ Any

\footnotetext{
${ }^{3}$ Whitehead does not explicitly mention Kant's third argument, the physiotheological one, or the claim that a "determinate experience" $(1996,600)$ can provide proof of God's existence. This is the line of argument more commonly known as natural theology, or the argument from design. It maintains that the "manifoldness, order, purposiveness, and beauty" of the empirical world are such as to point to, and indeed necessitate, the existence of a Creator or Designer (602). Kant rejects this argument, because "no experience at all can ever be congruent with," or adequate to,
} 
attempt to ground immanence in transcendence, or explain "stubborn fact" (the empirically given) by reference to an Absolute, would violate Whitehead's "ontological principle," which states that "there is nothing which floats into the world from nowhere" (244), that "every explanatory fact refers to the decision and to the efficacy of an actual thing" (46), and that, therefore, "the reasons for things are always to be found in the composite nature of definite actual entities" (19).

The one philosophical account of God that would seem to be exempt from this Kantian critique, and that does not violate the ontological principle, is Spinoza's. For Spinoza does indeed propose an entirely immanent God, who does not transcend the given world, but is coextensive with it (Deus sive Natura). Nonetheless, and even though his own philosophy "is closely allied to Spinoza's scheme of thought," Whitehead rejects the Spinozistic God, just he does the Leibnizian one (1929/1978, 7). For Spinoza still privileges God excessively. Even in Spinoza's monistic, immanent account of substance, "the ultimate is illegitimately allowed a final, 'eminent' reality, beyond that ascribed to any of its accidents." Spinoza distinguishes between substance and its attributes, on the one hand, and the multiple "individualized modes," or affections of this substance, on the other. This in itself is unexceptionable; "in all philosophic theory there is an ultimate which is actual in virtue of its accidents." But Whitehead warns us that this ultimate "is only then capable of characterization through its accidental embodiments, and apart from these embodiments is devoid of actuality" (7). That is to say, the ultimate - or what Whitehead also calls "creativiy" (21) - is altogether virtual or potential. It has no actuality of its own, but exists merely through its actualizations or embodiments. It cannot be conceived as an "actual entity" at all, "for its

the Idea of a transcendent Being. Kant's argument is a formalization of Hume's demonstration, in Dialogues Concerning Natural Religion (1998), of the indeterminacy of the argument from design: if we do not limit induction to the empirical world, then nearly any transcendent conception, no matter how bizarre, can be equally well inferred from our observations of empirical order.

Whitehead implicitly follows Kant's rejection of the physiotheological proof, in the very way that he structures his own argument. In his discussion of Religion in the Making (1926/1996), Whitehead proceeds from the "fact" of humankind's "religious experience" (86); he is concerned with the social, psychological, and affective basis of religion, rather than with its possible objective truth. From this perspective, the argument from design is itself an emotional response. It arises, as religion itself does, from our sense of wonder at the universe, and from humankind's long habit of "artificially stimulating emotion" through ritual (22). But the emotions that are both the cause and the effect of religious practices cannot in themselves count as proof for any conception of God. If anything, religion's "authority is endangered by the intensity of the emotions which it generates. Such emotions are evidence of some vivid experience; but they are a very poor guarantee for its correct interpretation" (83). 
character lacks determinateness." Correlatively, the "temporal world" as a whole cannot be regarded "as a definite actual creature," because all actual entities are complete in themselves, whereas the world as a whole "is an essential incompleteness" (1926/1996, 92).

According to Whitehead's reading, Spinoza ignores all this, to the extent that he grants a higher, more "eminent" order of reality to substance itself, or to what he calls God, than he does to the merely finite accidents of substance. Spinoza's God may be immanent, or coextensive with the world, but this only compounds the difficulty. For Spinoza's monism thereby treats the world as a totality, entirely apprehensible through God, or through the "third kind of knowledge." The "eminence" of the ultimate as creator (natura naturans) is replicated in the form of a total knowledge through first causes of the world as creature (natura naturata). And there is still a "gap" between this ideal knowledge and the actual existence of a "multiplicity of modes," each with its own particular actions and passions (Whitehead 1929/1978, 7). Spinoza eliminates empirical contingency; and with it, he disallows all novelty, all hope for a future different from the past. Spinoza's error, therefore, is precisely to substantialize the ultimate, to treat the totality of all accidents (or, more precisely, the total set of conditions for the "thoroughgoing determination" of all conceivable "accidental embodiments") as if it were somehow actual in itself. In this way, Spinoza remains within the bounds of speculative theology, and his notion of God remains susceptible to Kantian critique.

I have dwelt at such length upon Whitehead's criticisms of Spinoza and Leibniz precisely because, in spite of everything, their notions of God are closer than anyone else's to his own. Whitehead especially values these two thinkers, because they stand apart from the otherwise ubiquitous dualism of post-Cartesian thought (1925/1967, 143). But nevertheless, on a broader time scale, Spinoza and Leibniz do not escape the compromises made by their peers. Like nearly all thinkers of the last two thousand years, they allow "ethical and religious interests... to influence metaphysical conclusions" (173). Leibniz's mathematizing God, and Spinoza's immanent and impersonal one, are preferable to the Deity of actually existing Christianity, or to the notion of "a personal God in any sense transcendent or creative" (1926/1996, 87). But Leibniz and Spinoza still share traditional ethical and religious biases. "Dispassionate criticism of religious belief is beyond all things necessary" (83). But Leibniz's "pious dependence upon God" to shore up his metaphysics $(1929 / 1978,190)$ prevents him from doing this; and even Spinoza - radical as he is in his deconstruction of religious revelation and authority in the 
Tractatus Theologico-Politicus - does not sufficiently provide it.

Whitehead is not usually thought of as a "critical" thinker, in the Kantian mold. But his "criticism of religious belief" is precisely a Kantian, transcendental one, rather than a Spinozian, immanent one. This "criticism," in turn, is what motivates his own construction of the figure of God. For Whitehead does not announce the "death of God," just as he does not announce the "end of metaphysics." $\mathrm{He}$ bypasses Nietzsche, no less than Heidegger. Rather than rejecting metaphysical speculation, Whitehead seeks for a way to do metaphysics otherwise. And rather than eliminating God, he seeks to accomplish "the secularization of God's functions in the world" $(1929 / 1978,207)$. This is one of the most startling proposals in all of Process and Reality. The secularization of God, Whitehead writes, "is at least as urgent a requisite of thought as is the secularization of other elements in experience."

In saying this, Whitehead positions himself within the general Enlightenment project of emancipation - but with a twist. For secularization is not the same thing as outright elimination. It works in a way that is quieter, and less confrontational. Religion is not abolished, nor even really deposed; but it does lose a certain degree of importance. "The concept of God is certainly one essential element in religious feeling. But the converse is not true: the concept of religious feeling is not an essential element in the concept of God's function in the universe" (207). Religion, for Whitehead, is not without value; it may even be pragmatically indispensible, to the extent that it conveys a "longing of the spirit" for some sort of "justification" of its own existence, and of existence generally $(1926 / 1996,85)$. But religion, like science, still occupies only a subordinate position in Whitehead's overall scheme of values. "Religion requires a metaphysical backing" (83), which means that theology, like ethics, is subordinate to metaphysics and cosmology. Whitehead seeks to establish a God without religion, in the same way that he seeks to articulate a metaphysics without essentialism, and that he seeks to respect the findings of physical science without endorsing science's reductionist positivism, or its tendentious separation of facts from values.

What might the "secularization" of God actually entail? There is only one model for such an undertaking. In Science and the Modern World (1925/1967), Whitehead credits Aristotle with being "the last European metaphysician of first-rate importance" to contemplate God disinterestedly, and in a truly philosophical manner. Aristotle alone, in his conception of the Prime Mover, approaches the question of God in an "entirely dispassionate" way, with "no motive, except to follow his 
metaphysical train of thought withersoever it led him." Aristotle posits the figure of an ultimate being, not for extrinsic (ethical, religious, or theological) reasons, but only because "the general character of things requires that there be such an entity" (173-174). Aristotle is thus the last pre-religious thinker of God; Whitehead proposes to be the first post-religious, or secular, one.

Whitehead needs to divest himself of theology, which of course is something that Aristotle never had to do. But Whitehead parallels Aristotle in that his own approach to divinity is equally a matter of "follow[ing] his metaphysical train of thought withersoever it [leads] him." Whitehead posits God, neither out of piety and devotion, nor as a defense against nihilism and chaos, but simply because his own logic requires it. As Isabelle Stengers often reminds us, when Whitehead does metaphysics and cosmology, he continues to think like the mathematician he started out as being. That is to say, he poses a specific problem, and works under the "obligation" to construct a solution that establishes coherence, while respecting all the constraints and conditions imposed by the problem (Stengers 2002, 17 and passim). In this sense, Whitehead's God is a construction, necessary for the coherence and adequacy of his understanding of the world. Aristotle posited his Prime Mover because he was "enmeshed in the details of an erroneous physics and an erroneous cosmology." He "required" an originary source of motion, because he wrongly supposed that things would not continue to move on their own. Today, we know from the Principle of Inertia that things do not need a Mover in order to continue moving. But in the modern age of relativity and quantum mechanics, "an analogous metaphysical problem arises which can be solved only in an analogous fashion. In the place of Aristotle's God as Prime Mover, we require God as the Principle of Concretion" (1925/1967, 174). That is to say, we need God in order to explain "the puzzling fact that there is an actual course of events which is itself a limited fact, in that metaphysically speaking it might have been otherwise" (172). We need God in order to move from the potential to the actual: in order to make the wave function collapse, so that quantum indeterminacy can give way to a determinate physical outcome. Whitehead devises his own notion of God in order to resolve the problem of how a concrete and limited "actuality" can coherently exist "in essential relation to an unfathomable possibility" (174).

\footnotetext{
${ }^{4}$ The verb "to require" has particularly strong implications for Whitehead. It denotes a vital, imperious necessity that is grounded neither in formal logic nor in actual matter of fact. It is a kind of transcendental imperative, although in Kantian language it is a "hypothetical" and not a "categorical" one. Stengers describes Whitehead's sense of what "we require" as a demand, a "cry of the... soul," leading to an "experience of transformative disclosure." For instance, we "require,"
} 
Why is God needed as a Principle of Concretion? Coherence is the crucial issue here. The notion of coherence is so important to Whitehead that he defines it on the very first page of Process and Reality (1929/1978): " 'Coherence,' as here employed, means that the fundamental ideas, in terms of which the scheme is developed, presuppose each other so that in isolation they are meaningless. This requirement does not mean that they are definable in terms of each other; it means that what is indefinable in one such notion cannot be abstracted from its relevance to the other notions" (3). Coherent terms cannot be reduced to one another, or to anything more basic; but they also cannot be separated from one another. Coherence, then, is more than just a logical entailment. It it something quite different from, and greater than, mere " 'logical' consistency, or lack of contradiction" though this latter is also, of course, required in metaphysical speculation (3). For coherence implies, not just non-contradiction in principle, but also a kind of contextual solidarity. The principle of coherence stipulates that "no entity can be conceived in complete abstraction from the system of the universe" (3). In order to exist, a given entity presupposes, and requires, the existence of certain other entities, even though (or rather, precisely because) it cannot be logically derived from those other entities, or otherwise explained in their terms. Coherence means, finally, that "all actual entities are in the solidarity of one world" (67).

In other words, coherence is not logical, but ecological. It is exemplified by the way that a living organism requires an environment or milieu - which is itself composed, in large part, of other living organisms similarly requiring their own environments or milieus. In this way, and despite the difference in vocabulary, Whitehead's coherence is close to what Deleuze and Guattari (1987) call consistency. For "consistency concretely ties together heterogeneous, disparate elements as such" (507): it means that things are irrevocably connected to one another, without having any sort of underlying element in common. In Deleuze and Guattari's famous example, the orchid and the wasp are coupled, the flower feeding the insect, and the insect fertilizing the flower. In themselves, these two beings "have absolutely nothing to do with each other" (10), and yet neither can survive without the other. Whitehead's notion of coherence and Deleuze and Guattari's notion of consistency are both principles yoking together elements that nonetheless remain singular, and disjunct from one another. Both notions posit a world

not a proof that reductionism is wrong, but rather the positive capacity actually to think and act non-reductively (Stengers 2005, 42-43). Whitehead's "requirement" is the demand to fulfill a metaphysical "obligation"; this is why it can only be met by means of a "construction," in the mathematical sense of the term. Whitehead's God is precisely such a construction. 
in which everything is connected to everything else. However, these connections are not principles of internal definition or determination. Rather, they remain what Manuel DeLanda (2006) calls "relations of exteriority" (10ff). Such relations are "contingently obligatory," rather than "logically necessary"; they arise in the course of a history that could have been otherwise (11). ${ }^{5}$

On the highest level of generality, then, Whiteheadian "coherence" has to do with the way that things - or, more precisely, events - are entirely interdependent, yet also mutually independent. The world is both a disjunctive multiplicity of discrete entities, and a continuous web of interconnections. Neither of these dimensions

\footnotetext{
${ }^{5}$ Delanda follows Deleuze in insisting that, although an entity is always involved in relations with other entities, "a relation may change without the terms changing" (Delanda 2006, 11, citing Deleuze and Parnet 2002, 55). An entity is never fully defined by its relations; for it is always possible to detach an entity from one particular set of relations, and insert it instead in a different set of relations, with different other entities. Every entity has certain "properties" that are not defined by the set of relations it finds itself in at a given moment; the entity can take these properties with it when it moves from one context (or one set of relations) to another. At the same time, an entity is never devoid of (some sort of) relations: the world is a plenum, indeed it is over-full, and solipsism or atomistic isolation is impossible.

Put differently, no entity can be entirely isolated, because it is always involved in multiple relations of one sort or another, and these relations affect the entity, cause it to change. But this is not to say that the entity is determined by these relations. For the entity has an existence apart from these particular relations, and apart from the other "terms" of the relation, precisely insofar as it is something that is able to affect, and to be affected by, other entities. The entity is not just a function of its present relations, but of a whole history of relations in which it has affected other entities and been affected by them.

DeLanda thus distinguishes between the properties of an entity (which are what it takes with it to another context) and the capacities of that same entity (its potential to affect, and to be affected by, other entities). "These capacities do depend on a component's properties but cannot be reduced to them since they involve reference to the properties of other interacting entities" $(2006,11)$. An entity's capacities are as real as its properties; but we cannot deduce the capacities from the properties; nor can we know (entirely) what these capacities are, aside from how they come into play in particular interactions with other particular entities.

Whitehead's notion of coherence is largely consistent with Delanda's account of relations of exteriority. The difference is that Delanda has no account of process, or of how the shift from one set of relations to another actually occurs. His ontology is excessively, and needlessly, static. Whitehead avoids this problem, because he identifies entities with processes, which all at once become and thereby perish. Delanda's entities correspond, not to Whitehead's "actual entities," but rather to what Whitehead calls societies. Societies are aggregations of actual entities; these aggregations possess spatial extent and temporal duration, which is what allows them to affect and be affected by other societies. What Delanda calls the innate "properties" of an entity (as distinct from its capacities) would be defined by Whitehead rather as the aggregate of the free (not predetermined) "decisions" made by all the actual entities that constitute the society in question.
} 
can be ignored; "the individuality of entities is just as important as their community" (1926/1996, 88). Whitehead posits an "extensive continuum" (1929/1978, 61-82), that "involves both the property of indefinite divisibility and the property of unbounded extension," and that "expresses the solidarity of all possible standpoints throughout the whole process of the world" (66). But this continuum "is not a fact prior to the world" (66). That is to say, it does not have transcendental status, the way time and space do in Kant. The extensive continuum is rather just an empirical condition, that "expresses a fact derived from the actual world and concerning the contemporary actual world" (66). The extensive continuum contains certain potentialities within it; but it does not express "the 'general' potentiality, which is the bundle of possibilities, mutually consistent or alternative, provided by the multiplicity of eternal objects" (65).

Before the extensive continuum, or behind it, "the ultimate metaphysical truth is atomism" (35). Whitehead's philosophy is "an atomic theory of actuality" (27). In the actual world, "each ultimate unit of fact is a cell-complex, not analysable into components with equivalent completeness of actuality" (219). And in every incident of becoming, "actual entities atomize the extensive continuum. This continuum is itself merely the potentiality for a division; an actual entity effects this division" (67). This means that existence is continually being actualized, and thereby also spatialized and temporalized. Those "ultimate unit[s] of fact," or actual occasions, thus both precede the extensive continuum, and presuppose it. They precede the continuum, because they generate the space and time of which it is composed in the first place. But they also presuppose it, because they "effect [its] division" into discrete chunks of experience, or into the actual quanta of spacetime. In this way, from the quantum level on up, each "actual occasion," or process of becoming, both embodies interconnection, and asserts its own independence from all the past occasions from which it is derived, and to which it is connected. It both inherits everything that comes before it, and breaks away from everything that it inherits. Each "novel entity is at once the togetherness of the 'many' which it finds, and also it is one among the disjunctive 'many' which it leaves; it is a novel entity, disjunctively among the many entities which it synthesizes. The many become one, and are increased by one. In their natures, entities are disjunctively "many' in process of passage into conjunctive unity" (21). Conjunction and disjunction, unification and diversification, must always go together.

Each of Whitehead's "actual occasions" thus marks the point of a synthesis, taking this word in the strict Kantian sense: "by synthesis, in the most general sense 
of the term, I mean the act of putting various presentations with one another and of comprising their manifoldness in one cognition" (Kant 1996, 130). Whitehead, of course, rejects Kant's overall subjectivist and cognitivist orientation. But the crucial point here is that, for Kant, the cognitive faculty does not itself produce the synthesis. "Rather, synthesis of a manifold... is what first gives rise to a cognition... Hence, if we want to make a judgment about the first origin of our cognition, then we must first direct our attention to synthesis" (130). That is to say, synthesis precedes cognition, and alone renders cognitive judgment possible. In itself, the act of synthesis is primordial, prelogical, and precognitive. Synthesis is an action "produced by the imagination, which is a blind but indispensible function of the soul without which we would have no cognition whatsoever, but of which we are conscious only very rarely" (130). Kant's whole philosophy is organized around the question of synthetic judgment; but here, the constructive act of synthesis is separated from, and placed before, any judgment whatsoever. Kant's notion of synthesis is thus one of the ways that, as Whitehead says, he "first, fully and explicitly, introduced into philosophy the conception of an act of experience as a constructive functioning" $(1929 / 1978,156)$.

It is very much in this Kantian and Whiteheadian spirit that Deleuze, first in The Logic of Sense $(1990,174)$ and then more expansively (with Guattari) in AntiOedipus (1983, passim), proposes three basic syntheses of experience: the connective, the disjunctive, and the conjunctive. These syntheses are all modes of production; and what they produce is the Real itself. Or, better, these syntheses do not produce reality, so much as they are, themselves, the ultimate, "molecular" components of reality. "Everything is production: production of productions, of actions and passions [connective synthesis]; productions of recording processes, of distributions and of co-ordinates that serve as points of reference [disjunctive synthesis]; productions of consumptions, of sensual pleasures, of anxieties, and of pain [conjunctive synthesis]" (Deleuze and Guattari 1983, 4). A productive synthesis corresponds to what Whitehead calls a concrescence: the "production of novel togetherness" (Whitehead 1929/1978, 21), or the coming-together of multiple prehensions into "one determinate integral satisfaction" (26). The syntheses are processes that aggregate other processes, or perspectives upon things that are themselves also perspectives (since "there are no points of view on things, but...things, beings, are themselves points of view" - Deleuze 1990, 173). They are productions whose "raw materials" are other productions, and whose "products" are themselves taken up as materials in further processes of production. ${ }^{6}$

\footnotetext{
${ }^{6} \mathrm{~A}$ synthesis is therefore not quite the same thing as a Spinozian conatus, or striving to persist
} 
Every synthesis ends in what Whitehead would call its "satisfaction," which is also the "objective immortality" of having become an object, or a product. This is how the world is always being "given" to us (and not only to us), as something already there, already accomplished. But this accomplishment is never final. For immediately, "the pure 'thisness' of the object produced is carried over into a new act of producing... The rule of continually producing production, of grafting production onto the product, is a characteristic of desiring-machines or of primary production" (Deleuze and Guattari 1983, 7).

When they evoke this first, connective synthesis of primary production, Deleuze and Guattari seduce us with an enticing picture. How nice it would be, they tell us, if we could live in a wholly immanent, happily pluralistic world. Such a world would be a "plane of immanence" of pure process and pure desire. There would be nothing but flows, nothing but rhizomes, nothing but connections and cuts. Everything would flow, and every flow would intersect with many other flows. Everything would be connected to everything else; "any point of a rhizome can be connected to anything other, and must be" $(1987,7)$. In such a world, desire would not know deferral, and production would be indistinguishable from play. "Desire constantly couples continuous flows and partial objects that are by nature fragmentary and fragmented. Desire causes the current to flow, itself flows in turn, and breaks the flows... Amniotic fluid spilling out of the sac and kidney stones; flowing hair; a flow of spittle, a flow of sperm, shit, or urine" $(1983,5)$. In such a

in being. Deleuze and Guattari warn us that a synthesis, or a process of production, "must not be viewed as a goal or an end in itself; nor must it be confused with an infinite perpetuation of itself" $(1983,5)$. It is oriented towards becoming, rather than continuation.

More generally, there is a subtle, and never fully explored, tension in Deleuze's work (both with and without Guattari) between two different ways - closely related but nonetheless distinct - of conceiving the process of auto-creation. On the one hand, there is Spinoza's conatus, best defined as "a tendency to maintain and maximize the ability to be affected" (Deleuze 1988, 99, citing Spinoza's Ethics IV 38). Conatus is quite close to Varela's concept of autopoiesis, the process by which a relational system maintains itself through dynamic interaction with its environment, recreating the very processes that produce it. On the other hand, there is Gilbert Simondon's notion of individuation, the process by which an entity continually reconstitutes itself by actualizing potentials that pre-exist in a metastable environment. Individuation has strong affinities with Whitehead's concrescence, the way that an entity constitutes itself as something radically new, by selecting among, and recombining, aspects of already-existing entities. All four of these terms (conatus, autopoiesis, individuation, concrescence) imply a certain sort of auto-creation, in which virtualities are actualized. But in conatus and autopoiesis, the emphasis is on a continuity that is created and preserved in and through continual change and interaction with the environment; whereas, in individuation and concresence, the emphasis is on the production of novelty, the entity's continual redefinition, or becoming-other than what it was. 
world, everything would proliferate and transmogrify, continually renewing itself in the process: "at the limit-point of all the transverse or transfinite connections, the partial object and the continuous flux, the interruption and the connection, fuse into one: everywhere there are breaks-flows out of which desire wells up" (36-37). Deleuze and Guattari thus depict a world of gratified desire: a world in which everything is process, and nothing is ever static or self-contained. Life is then a continual wonder of strange encounters and wild metamorphoses.

But Deleuze and Guattari also warn us that things are never really that simple. The rhizomatic, connected world of pure desire is not the world that we live in. Things don't actually happen in so direct and unmediated a way. Indeed, if the world really were this way - that is, if it were always and only this way - then nothing would ever happen at all. If the world were entirely composed of flows and cuts, connections and intersections, then everything would remain in a state of mere potential. Nothing could ever be accomplished or actualized, and nothing could be distinguished from anything else. If the world were entirely composed of singularities, then there would be no "series of ordinary points" over which those singularities could be extended or expressed (Deleuze 1990, 109ff.). In such a world, there would be no continuities and no consequences. Everything would contain an immense "potential for every becoming" (Whitehead 1929/1978, 22), but nothing would ever actually become. ${ }^{7}$

In other words, once "we conceive actuality as in essential relation to an unfathomable possibility," then some sort of "Principle of Concretion" is needed, in order for anything to be actualized at all (Whitehead 1925/1967, 174). The connective synthesis is not in itself enough to define the actual becoming of a world. This is why, alongside the connective synthesis of flows and cuts, there must also be a disjunctive synthesis of routes and permutations. The economy of production (Deleuze and Guattari 1983, 5-6) is supplemented by an economy of circulation and distribution (12). This supplemental economy corresponds to a torsion in

\footnotetext{
${ }^{7}$ It is precisely on these grounds that Ernst Bloch $(1986,201)$ criticizes Bergson, the common predecessor of Whitehead and Deleuze. Bloch warns us that relentless novelty can itself become wearyingly repetitious and static. Incessant innovation, without real consequence, simply results in boredom: the continual passage of "senselessly changing fashions," the "rigidity of a surprise that is always the same." A "constantly required change of direction, required for its own sake," ends up taking us nowhere in particular, but only through the endless "zig-zag" of a random walk. The trouble with a process metaphysics, Bloch says, is that "the process remains empty and repeatedly produces nothing but process." It never arrives at any finished product; and therefore it never arrives at the Novum, the genuinely new. Instead, "the process remains empty and repeatedly produces nothing but process."
} 
the field of desiring production. The connective synthesis is still more or less straightforward, in the sense that its logic remains linear, or at most "multilinear" (1987, 295ff.). But the disjunctive synthesis of recording is far more convoluted and indirect. Its twists and turns are those of Nietzsche's "abyssal thought" of the Eternal Return (Deleuze 1990, 264), or of the "most terrible labyrinth of which Borges spoke" (176). For the disjunctive synthesis does not just split and connect terms in series. Rather, it "endlessly ramif[ies]" (59) the entire series of terms. It presents a "system of possible permutations between differences that always amount to the same as they shift and slide about" (Deleuze and Guattari 1983, 12). The disjunctive synthesis establishes a positive relation among a multiplicity of radically incompatible alternatives. It affirms all these alternatives together, indiscriminately, and defines itself in terms of the distances that separate them from one another. It is "an operation according to which two things or two determinations are affirmed through their difference," on the basis of "a positive distance of different elements" (Deleuze 1990, 172).

The disjunctive synthesis is deeper and more basic than logical contradiction, which it at once precedes, generates, and exceeds. It is not the case that two items are affirmed disjunctively, because they logically contradict one another. It is rather that they can only contradict one another logically, as a result of their having first been put into contact by the workings of the disjunctive synthesis. Two items can only be in contradiction if they have already actively clashed with one another pragmatically. As Deleuze puts it, "contradiction results always from a process of a different nature. Events are not like concepts; it is their alleged contradiction (manifest in the concept) which results from their incompatibility, and not the converse" $(1990,170)$. Whitehead makes a similar point, enunciating what he calls the "principle of compatibility and contrariety" (1929/1978, 148). Two items are "contraries to each other" when they "cannot coexist in the constitution of one actual entity." They have proven themselves to be incompatible, at least in this particular concrescence. But such an incompatibility is not a matter of logic. For " 'feelings' are the entities which are primarily 'compatible' or 'incompatible.' All other usages of these terms are derivative" (148). Another concrescence, productive of another actual entity, might well exhibit vastly different feelings; the "subjective form" with which it prehended its data would be different. It might then be able to positively prehend both items, thereby rendering them compatible. It would thus "convert its exclusions into contrasts" (223). Whitehead's conversion of exclusions into contrasts, like Deleuze's disjunctive synthesis, cannot be 
defined in terms of negativity and contradiction. ${ }^{8}$

In making these arguments, Whitehead and Deleuze both draw upon Leibniz, with his notions of compossibility and incompossibility. These notions, Deleuze (1990) says, "must be defined in an original manner"; they do not presuppose "the identical and the contradictory," but are themselves the primordial grounds for our judgments of identity and contradiction (173). Events, which in themselves are pure singularities, and hence fundamentally neutral and impassive, enter into relations of compossibility and incompossibility with one another, before questions of logic can even arise. It is only when two events turn out to be incompatible - that is to say, when they cannot occur in the same timeline, or occupy places in the same "possible world," because the actualization of one would block the actualization of the other - that we can therefore say, derivatively, that the states of affairs corresponding to these two events are logically contradictory. The disjunctive "communication of events" (169-176) exceeds any logic of identity and contradiction, even as it alone provides the necessary conditions for judgment according to such a logic.

The disjunctive synthesis takes the grammatical form of an indefinitely extended "either... or... or..." (Deleuze and Guattari 1983, 12). ${ }^{9}$ Things may happen this way, or they may happen that way, or they may happen yet another way, without any definitive preference. This is a Leibnizian situation, a movement among incompossibles; but for Deleuze and Guattari, as for Whitehead, there is no Leibnizian God to choose, among the incompossible series of events, the one that is most perfect or most fully real. Instead, all the series are affirmed in turn, as each

\footnotetext{
${ }^{8}$ This is why Deleuze (explicitly) and Whitehead (implicitly) both reject the Hegelian notion of contradiction as the motor of change, or of history. Deleuze is always concerned to define philosophical thought as a power of affirmation, rather than one of negation. But he is always quick to add that the negative still has its place, as long as we see "negations as powers of affirming," instead of invoking negativity "as a motor, a power, and a quality" in its own right $(1983,179)$. Every New necessarily provides its own negations; but negativity is not in any sense the inner principle of the New.

${ }^{9}$ In The Logic of Sense, Deleuze expresses the disjunctive synthesis with the phrase ou bien... ou bien, translated as "either... or" (1990, 174). In Anti-Oedipus, Deleuze and Guattari express it rather with the phrase soit... soit, translated as "either...or... or." This soit is then explicitly opposed to the ou bien (translated "either/or"): soit expresses an active, affirmative (inclusive and nonrestrictive) use of the disjunctive synthesis, while ou bien, implying as it does "decisive choices between immutable terms (the alternative: either this or that)," expresses its limitative and reactive (exclusive and restrictive) use (1983, 12; cf. 75ff.). The distinction between ou bien and soit is hard to convey in English. But the question of the difference between affirmative and limitative uses of the disjunctive synthesis is an important one, to which I return below.
} 
gives way to another, over and over again. As Deleuze summarizes the difference: "For Leibniz... bifurcations and divergences of series are genuine borders between incompossible worlds... For Whitehead (and for many modern philosophers), on the contrary, bifurcations, divergences, incompossibilities, and discord belong to the same motley world" $(1993,81)$. Such a world, with its process of disjunctively affirming incompossibles, is exemplified in late modernist fictions like Beckett's Malone (Deleuze and Guattari 1983, 12), Borges' “Garden of Forking Paths" (Deleuze 1990, 114), and Gombrowicz's Cosmos (Deleuze 1993, 154, n. 15) and Pornographia (Deleuze 1990, 289-290). It is also exemplified in the cinema of the "time-image," in which incompatible images and sounds are linked through the disjunctions of "irrational cuts" (Deleuze 1989, 181, 248, and passim). In all these works, "incompossible worlds, despite their incompossibility, have something in common," for they "appear as instances of solution for one and the same problem" (Deleuze 1990, 114).

Deleuze's allusion here to problems and solutions recalls the way that, in Difference and Repetition (1994), he equates problems with Kantian transcendental or regulative Ideas, seeing them as "focal points or horizons" that "embrace" multiple, incompatible solutions (168-169). Today we might say, in the language of complexity theory, that these incompossible worlds correspond to alternative paths through the same phase space. Or we might think of how the "many worlds" interpretation of quantum mechanics has figured in recent science fiction novels and comics. In Warren Ellis' Night on Earth (2003), for instance, the superheroes of the Planetary group are "rotated through the multiverse" from one actualization of Gotham City to another. As a result, they meet multiple iterations of Batman, from Bob Kane's avenger to Adam West's campy put-on to Frank Miller's borderline psychopath. Only one Batman can be encountered at a time, as his various iterations are incompatible with one another, and belong to incompossible worlds. But the disjunctive synthesis consists precisely in the restless movement from one Gotham City and Batman to another. No Gotham City and Batman can be privileged above the rest - not even Bob Kane's "original" conception, which is just as much a particular, circumstantial actualization as are all the others. Rather, the "positive distance" between the various iterations is what generates all of them, or "distributes the divergent series... and causes them to resonate through their distance and in their distance" (Deleuze 1990, 174). Each Batman is a particular "solution for one and the same problem," which is to say a particular actualization of the same constellation of potentialities, the same virtual configuration. 
The logic of the disjunctive synthesis is also the logic of the simulacrum. According to Deleuze's reading, Plato is always concerned "to select lineages: to distinguish pretenders; to distinguish the pure from the impure, the authentic from the inauthentic" $(1990,254)$. The crucial Platonic distinction is neither between the original and the copy, nor between the Ideas of the rational world and their images in the sensible world. It is rather a distinction within the sensible world itself, "between two sorts of images. Copies are secondary possessors. They are well-founded pretenders, guaranteed by resemblance; simulacra are like false pretenders, built upon a dissimilarity, implying an essential perversion or a deviation" (256). Copies refer back to an original (the Idea), and can be judged hierarchically on the basis of their fidelity to this original. On the other hand, "the simulacrum is built upon a disparity or upon a difference. It internalizes a dissimilarity. This is why we can no longer define it in relation to a model imposed on the copies, a model of the Same from which the copies' resemblance derives" (258). The simulacrum cannot be referred back to the originary Idea at all; it can only be understood as part of a "signal-sign system," one that is "constituted by placing disparate elements or heterogeneous series in communication" (261).

In this sense, Batman is a simulacrum. There is no Platonic Idea of Batman, no model that all the iterations of Batman would conform to more or less, and in relation to which they could all be hierarchically ranked according to the degree of their resemblance. There is also no best of all possible Batmans, no iteration which can be judged more perfect than all the rest. Rather, the disparity between the different iterations of Batman, their distance from one another, is itself the only common measure between them. Each Batman arises independently, as a unique "solution" to a common disparity or problem (let us say, to the young Bruce Wayne's primordial trauma of witnessing the murder of his parents). And between these solutions, "there is no longer any possible selection" (Deleuze 1990, 262). In the absence of any Platonic criterion, or any Leibnizian God, there is only the disjunctive synthesis which affirms each iteration, one at a time, in its divergence from all the rest. This means that any particular iteration of Batman is entirely contingent, although the synthesis itself, with its affirmation of all these mutiple iterations, responds to a necessity.

We might say, in the language of quantum mechanics, that all these disparate solutions or iterations correspond to the different outcomes when the wave function collapses. At some point, the wave function must collapse; but there is no telling, in advance, when this collapse will happen, or which alternative it will 
lead to. In Whitehead's terms, the multiple iterations of the disjunctive synthesis correspond to the ungrounded "decisions" that each actual entity must make, in the course of becoming itself. Every entity's decision is "internally determined and...externally free" $(1929 / 1978,27)$, precisely because there is no norm or standard to guide it, no antecedent principle of selection. The disjunctive synthesis is an expression of radical contingency: "It is true that any flux must exhibit the character of internal determination. So much follows from the ontological principle. But every instance of internal determination assumes that flux up to that point. There is no reason why there could be no alternative flux exhibiting that principle of internal determination" (46-47). The "logic" of this history, the reason things happened the way they did, can only emerge retrospectively.

Deleuze derives his account of the disjunctive synthesis from an analysis of the "disjunctive syllogism" by means of which Kant presents the Idea of God (1990, 294-297). As I have already mentioned, Kant's critique of speculative theology, in the section of the First Critique on "The Ideal of Pure Reason" (1996, 560-616), defines God, not as the origin or creator of the world (its first cause), but rather as the principle of the "thoroughgoing determination" of reality $(563,567)$. This means that everything that exists must be derived from God by a process of selection and limitation. The "thoroughgoing determination of any thing rests on the limitation of this total of reality," Kant says, "inasmuch as some of this reality is attributed to the thing but the rest is excluded" (567-568). God encompasses all possible predicates; but any finite individual thing includes only some of these predicates. Or as Deleuze puts it: "God is defined by the sum total of all possibility, insofar as this sum constitutes an 'originary' material or the whole of reality. The reality of each thing 'is derived' from it: it rests in effect on the limitation of this totality... [T] he sum total of the possible is an originary material from which the exclusive and complete determination of the concept of each thing is derived through disjunction" (Deleuze 1990, 295-296). Any individual thing must be either this or that; God's role is to be the community, the being-together, of all these alternatives. Through what Deleuze describes as Kant's "irony," God is "deprived of his traditional claims - to have created subjects or made a world" and presented instead, much more humbly, as merely "the principle or master of the disjunctive syllogism" (294-295). ${ }^{10}$

\footnotetext{
${ }^{10}$ As Deleuze (1990) more fully explains, Kant "poses [a link] between Ideas and syllogisms... This extraordinary theory of the syllogism.... consists in discovering the ontological implications of the latter" (294-295). The three Ideas of Reason that Kant analyzes in the "Transcendental Dialectic" are Self, World, and God. Each of these is aligned with one of Kant's three categories
} 
This means that Kant's God, like Leibniz's God, is basically a principle of selection: which is to say, of exclusion and limitation. "In Kant, therefore, we see that God is revealed as the master of the disjunctive syllogism only inasmuch as the disjunction is tied to exclusions in the reality which is derived from it, and thus to a negative and limitative use" (Deleuze 1990, 296). Deleuze opposes to this an affirmative and inclusive use of the disjunctive syllogism, which he finds in Klossowski's figure of the Baphomet (the Antichrist or anti-God). Under God, "a certain number of predicates are excluded from a thing in virtue of the identity of the corresponding concept." With the Baphomet, to the contrary, "each thing is opened up to the infinity of predicates through which it passes" (296). On the one side, each entity is locked into a fixed identity, because it is restricted to specific predicates; on the other side, each entity loses its identity, as it is opened up to the multiplicity of possible predicates through which it passes. The limitative order of the world, as guaranteed by God, is opposed to the affirmative order of the Baphomet, "a 'chaosmos,' and no longer a world" (176), which is characterized by "singularity, or even multiple singularities" rather than by fixed identities (297). The entities of the Baphomet's chaosmos do not have identity, because they are caught up in continual metamorphoses. But they can be described, nevertheless, as singularities, because - even as they pass through all possible predicates - they do not have these predicates all at once. Batman has no fixed identity, but each iteration of Batman is a singular one. ${ }^{11}$

of relation, and with one of the three kinds of syllogism. The Idea of the Self is correlated with the category of substance and the categorical syllogism, since this Idea "relates a phenomenon determined as a predicate to a subject determined as substance" (295). The idea of the World is correlated with the category of causality and the hypothetical syllogism, for this is how one entity is linked to another through the chains of cause and effect. These links determine the genesis and becoming of the world as a whole. Finally, the idea of God is correlated with the category of community and the disjunctive syllogism. That is to say, it is through God - defined as the being whose task is "to enact disjunctions, or at least to found them" (295) - that all the entities of the world can be said to reciprocally determine one another, so that they cohere together as a system (cf. Kant 1996, 136: "community is the causality of a substance reciprocally determining [and being determined by] another substance"). Deleuze and Guattari's revision or correction of Kant in Anti-Oedipus consists in referring each of these clusters of Idea, category, and relation back to a corresponding synthesis. The Idea of Self is derived from the conjunctive synthesis; the Idea of the World from the connective synthesis, and the Idea of God from the disjunctive synthesis.

${ }^{11}$ The fact that the disjunctive syllogism, or synthesis, passes through its multiple predicates one at a time, discarding each one as it affirms another, is what separates it from the movement of the Hegelian dialectic. Hegel famously writes that the "arising and passing away" of Appearance is the one thing that "does not itself arise and pass away," and that "the True is thus the Bacchanalian revel in which no member is not drunk" (Hegel 1977, 27). This formulation does not thus 
However, it may well be that Deleuze draws too abrupt a distinction between negative and affirmative uses of the disjunctive synthesis. In Anti-Oedipus, Deleuze and Guattari state that "for the exclusive and restrictive use of the disjunctive synthesis, [the schizophrenic] substitutes an affirmative use... That is why the schizophrenic God has so little to do with the God of religion, even though they are related to the same syllogism" (1983, 76-77). As any deconstructionist will gleefully point out, this amounts to making an exclusive use of the disjunctive synthesis, in the very act of defending its affirmative, inclusive use. But Deleuze himself is fully aware of this criticism, and does not seem particularly bothered by it. As he notes, "we have seen, however, how often negative or exclusive disjunctions still subsist in Klossowski's work," especially "between God's order and the order of the Antichrist. But it is precisely inside God's order, and only there, that disjunctions have the negative value of exclusion. And it is on the other hand, inside the order of the Antichrist, that the disjunction (difference, divergence, decentering) becomes as such an affirmative and affirmed power" (Deleuze 1990, 296-297). This suggests a Nietzschean reversal of perspectives (cf. 173), a continual movment back and forth between the order of God on the one hand, and the order of the Antichrist on the other. In one direction, the disjunctive synthesis tends towards exclusion; in the other direction, towards multiplicity and affirmation. But neither of these movements is ever completed. No identity is ever so firmly in place as to resist all modification; and affirmative metamorphosis, by its very nature, is always incomplete and partial. This is why Deleuze and Guattari can proclaim, incorporating both ways of using the synthesis: "To anyone who asks: 'Do you believe in God?' we should reply in strictly Kantian or Schreberian terms: 'Of course, but only as the master of the disjunctive syllogism, or as its a priori principle (God defined as the Omnitudo realitatis, from which all secondary realities are derived by a process of division)' "' (1983, 13).

far contradict the Baphomet's affirmative use of the disjunctive syllogism. But Hegel adds that "the revel is just as much transparent and simple repose," and that "in the whole of the movement, seen as a state of repose, what distinguishes itself therein, and gives itself particular existence, is something that recollects itself [das sich erinnert], whose existence is self-knowledge, and whose self-knowledge is just as immediately existence" (27-28). In Klossowski's and Deleuze's accounts of the disjunctive syllogism, to the contrary, there can be no such repose. Recollection (Erinnerung) is impossible. There is no gathering-together of the dispersed limbs of Dionysus. The movement of the disjunctive syllogism is not one of recollection, bu rather one of continual forgetting - as Klossowski especially emphasizes in his discussion of Nietzsche's Eternal Return (1998), upon which Deleuze quite heavily draws. Disjunctive syntheses therefore cannot be equated with Hegelian "syntheses of contradictory elements" (Deleuze and Guattari 1983, 76). 
Indeed, Kant himself moves beyond a merely limitative use of the disjunctive syllogism. For he insists that "the derivation of all other possibility" from the original nature of God "cannot, strictly speaking, be regarded as a limitation of this being's supreme reality and, as it were, a division of this reality... Rather, the supreme reality would underlie the possibility of all things as a basis [Grund], and not as a sum. And the manifoldness of those things would rest not on the limitation of the original being itself, but on that of its complete consequence" $(1996,569)$. This means that "limitation" is just a defective manner of speaking - even if, given our lack of access to any transcendent reality, it turns out to be an unavoidable one. God, as the master of the disjunctive syllogism, must actively distribute the disjunctions that constitute reality, deriving them as positive consequences of his own being - rather than acting as a principle of limitation. In this way, Kant's God is not opposed to Klossowski's Baphoment, so much as the two are inextricably conjoined. We might even say that Kant passes over to the side of the Baphomet, to the extent that he warns us against the "natural illusion" of trying to "hypostasize this idea of the sum of all reality" (571). Empirically, all we can understand is "the passage of each thing through all of its possible predicates" (Deleuze 1990, 296); we can reach the "determinability" of all things in this way, but we cannot ever know the presumed principle of their complete determination.

In all this, Kant affirms the "a priori principle" of disjunction - even at the expense of the figure of God himself. In his discussion of the "Transcendental Ideal" of the "thoroughgoing determination" of reality, Kant points out that the mere presentation of such an ideal "does not presuppose the existence of such a being as conforms to this ideal" (568). Kant's argument treats God only as a personification of the disjunctive syllogism (cf. 572, note 83). This is a very different matter from attributing the power of operating the disjunction to a God whose existence would already have been established on other grounds. Indeed, it is precisely Kant's characterization of God in terms of the disjunctive syllogism that allows him to refute the traditional arguments for God's existence. When God is defined as the principle of the disjunctive syllogism, and thereby invested with all possible predicates, the ironic result is to divest him of the so-called "predicate of existence." For "no matter through which and through how many predicates I think a thing. .. not the least is added to this thing by my going on to say that this thing $i s "$ (584). Even all the possible predicates in the universe gathered together cannot add up to any necessary existence. The idea of God as master of disjunctions allows us to represent the world disjunctively, as a "distributive unity"; but such a unity is a limited one, and "does not allow us to conclude that his Idea 
represents a collective or singular unity of a being in itself which would be represented by the Idea" (Deleuze 1990, 296, referring to Kant 1996, 571-572). In other words, to say that existence is not a predicate is to say that the philosophical idea of God - as the priniciple of the disjunctive synthesis, or of the "thoroughgoing determination" of reality - is not a constitutive idea, but only a regulative (or problematic) one. And this is why Kant insists that God's existence cannot be proven cognitively, but only affirmed practically (as happens in the Second Critique).

In Anti-Oedipus, Deleuze and Guattari replace Kant's God with what they call the Body without Organs (BwO). Following the opposition between God and Antichrist already established in The Logic of Sense, they say that "the body without organs is not God, quite the contrary" (1983, 13). I've been trying to suggest, however, that this opposition is a bit too hasty. The conditions as Deleuze and Guattari actually describe them are a lot more tangled. The Body without Organs, just like Kant's God, oscillates between the two poles of the disjunctive synthesis. At times, it is exclusive and restrictive, like Leibniz's God with its exclusion of incompossibles. At other times, it is inclusive and nonrestrictive, in the manner of Schreber's God or Klossowski's Baphomet. This follows from the way that the Body without Organs is introduced as "a third term" (7), interrupting the binary logic of the connective synthesis of flows and cuts. The Body without Organs is a recording surface, a site of inscription for this disjunctive synthesis. "Everything stops dead for a moment, everything freezes in place - and then the whole process will begin all over again" (7). The Body without Organs is not itself a dynamic process. It is rather "an enormous undifferentiated object... the unproductive, the sterile, the unengendered, the unconsumable" (8). It does not itself flow, does not connect and cut; but every flow passes over it, and every cut is recorded upon it. For every "process of production" requires "an element of antiproduction" (8), a point where the process stops altogether: in short, a dose of mortality. "From a certain point of view it would be better if nothing worked, if nothing functioned" (7). Deleuze and Guattari go so far as to identify the Body without Organs with the Freudian and Lacanian death drive: "for desire desires death also, because the full body of death is its motor, just as it desires life, because the organs of life are the working machine" (8). And this death, this antiproduction, is precisely a figure of God. ${ }^{12}$

\footnotetext{
${ }^{12}$ Angela Carter works through a similar dynamic in her novel The Infernal Desire Machines of Doctor Hoffman (1986). We are told that the novel's eponymous mad scientist (perhaps named after the discoverer of LSD) "was waging a massive campaign against human reason itself" by us-
} 
The notion of the Body without Organs is, of course, taken from the late writings of Antonin Artaud. Deleuze first introduces the Body without Organs in The Logic of Sense, where it is associated with a "universal depth," resulting from a catastrophic "collapse of the surface" (1990, 87). In Anti-Oedipus, however, Deleuze and Guattari associate the Body without Organs with a different concept developed in The Logic of Sense: the concept of quasi-causality. Deleuze and Guattari posit an "apparent conflict" $(1983,9)$ - a Kantian Antinomy - between the active material causality of desiring production, and the quasi-causal "antiproduction" of the Body without Organs. Just as quasi-causality, in The Logic of Sense, qualifies and alleviates the "poisonous mixtures" and "abominable necromancies" of material causality (1990,131), so in Anti-Oedipus the Body without Organs repels the "larvae and loathsome worms" of desiring production $(1983,9)$. And just as the Stoic doctrine of events, in The Logic of Sense, involves an exploration and elaboration of the surface, and the separation of this surface from the schizophrenic depths, so in Anti-Oedipus the Body without Organs "plays the role of a recording surface... an enchanted recording or inscribing surface that arrogates to itself all the productive forces and all the organs of production" that were previously rumbling in the depths $(1983,11-12){ }^{13}$

ing his "desire machines" to flood the city with waves of "actualized desire." In Doctor Hoffman's profusion of surrealistic "mirages" made flesh, "life itself had become nothing but a complex labyrinth and everything that could possibly exist, did so." With all possibilities, desires, and fantasies equally present, "nothing... was identical with itself any more." The result is "a complexity so rich it can hardly be expressed in language." However, the narrator, who ironically calls himself Desiderio, is "bored" by the wonders and complexities that Doctor Hoffman generates from his desire machines. He wearies of relentless novelty, and develops, instead, "an admiration for stasis" (12). "I myself had only the one desire," he says. "And that was, for everything to stop" (11).

${ }^{13}$ Even the figure of Oedipus plays an analogous role in both texts, despite the later book's attacks upon the logic of Oedipalization that was articulated in the earlier one. In The Logic of Sense, Oedipus is the "pacifying hero" who "dispelled the infernal power of depths and the celestial power of heights, and now claims only a third empire, the surface, nothing but the surface" $(1990,201)$. In Anti-Oedipus, this function is condemned rather than celebrated; but it remains the case "that Oedipus is a requirement or a consequence of social reproduction, insofar as this latter aims at domesticating a genealogical form and content that are in every way intractable" (1983, 13). In both texts, Oedipal quasi-causality tames (but cannot altogether master) the schizophrenic intensities produced in the depths of materiality and of bodies.

Anti-Oedipus is usually read as repudiating the depth/surface opposition that structured The Logic of Sense. But the actual relation between the two books is more complicated than such a formulation would indicate. In The Logic of Sense, quasi-causality is described as an effect of the surface; to the contrary, Artaud's Body without Organs is presented as a pure experience of the depths (1990, 82-93 passim). In Anti-Oedipus, however, the imageless figures of quasi-causality on the surface, and of the Body without Organs in the depths, are equated with one another. This 
Deleuze and Guattari offer the Body without Organs as their own solution to what Whitehead calls the problem of concretion. As Whitehead puts it, "Activity loses its meaning when it is reduced to 'mere creation now:' the absence of Value destroys any possibility of Reason" $(1951,684)$. At such a point, creativity is nothing more than incessant variation for its own sake, or what Bloch scathingly calls mere "capitalistic fashion-novelty" $(1986,201)$. In Deleuze's terms, this is the problem of actualization: although everything is process, there has to be more than just incessant process, in order for anything concrete to happen at all. When the connective synthesis runs all by itself, "the flows of energy are still too closely connected, the partial objects still too organic" (Deleuze and Guattari 1983, 8). For Deleuze and Guattari, the question is how to avoid both the idealized notion of a plenum with total continuity, in which nothing could happen because nothing would be missing, and the Hegelian logic of negativity and lack, in which absence and contradiction would be the motors of change. The Body without Organs is the solution to this Antinomy. For it is neither an integral whole nor an emptiness. Rather, as an "amorphous, undifferentiated fluid" (9), it is utterly ambiguous, partaking of both fullness and emptiness, but not reducible to either. "The body without organs is not the proof of an original nothingness, nor is it what remains of a lost totality" (8). It is best thought of as Being Degree Zero: that which stubbornly remains, resisting all negation, even when every positive quality has been taken away. The Body without Organs in itself produces nothing; but it must be "perpetually reinserted into the process of production" (8). Within the process, it makes things happen by imposing its pauses and blockages, disjunctions and alternatives. Desiring production always also involves antiproduction. Every cause is accompanied by its shadow: a quasi-cause that is ephemeral, "anonymous," and "nondifferentiated" (9), but altogether real for all that.

This is the point at which Deleuze and Guattari encounter Marx. There are two ways in which the logic of the Body without Organs can be identified with the logic of Capital that Marx describes. In the first place, when the Body without Organs interrupts and deadens production, it also captures the fruits of production (the products), attributes these products to itself, and distributes them all across

is why the Body without Organs is described as both a "recording surface" and a "full body." The "nondifferentiated" blankness of antiproduction is both a surface effect, and a deep "counterflow of amorphous, undifferentiated fluid" $(1983,9)$. Thus Anti-Oedipus retains both the distinction between surfaces and depths, and the distinction between material causality (production) and quasicausality (antiproduction); only it redistributes these two distinctions, instead of aligning them with one another. 
its surfaces. This is what Marx calls exploitation, or the extraction of surplus value. And in the second place, just as, for Marx, the surplus value extracted in the process of production cannot be realized without a concomitant movement of circulation, so, for Deleuze and Guattari, the productions of the connective synthesis cannot be actualized without the concomitant circulations and inscriptions of the disjunctive synthesis, as recorded on the surface of the Body without Organs. This is how the Body without Organs is a "machine" of both repulsion and attraction. It takes the form both of a "recording surface," and of what Deleuze and Guattari call the socius: "a full body" of social production (10). Under the capitalist mode of production, this socius is the body of Capital itself, "the body that Marx is referring to when he says that it is not the product of labor, but rather appears as its natural or divine presupposition" (10). Human labor is the actual, material cause of social reproduction today; but Capital is the quasi-cause, sterile and seemingly unengendered or self-engendered, upon whose surfaces this reproduction is recorded, through whose mediations it is organized, and to whose depths we cannot avoid attributing it. ${ }^{14}$

Marx describes how Capital arrogates the products of living labor to itself, so that it appears as if the surplus value extracted from that labor were a "natural" result of Capital's own autonomous process of "self-valorization." But this "appears as if" is not a mere falsification; part of Marx's point is that the self-valorization of Capital is, in its own right, a sort of objective illusion, or what Deleuze and Guattari call an "apparent objective movement" (1983, 10-11). In capitalism's image of itself, labor is placed alongside raw materials, machinery, rent, and so on as a mere input of production; profit is calculated as a function, and indeed a product, of the total capital advanced. The creative role of living labor is thereby occluded. But this image is not just a mystification (though it is also that). For it is less a false representation of the capitalist system, than it is an actual aspect of Capital's self-representation. And this "ideological" self-representation is itself necessary to Capital's own internal functioning. Entrepreneurs and enterprises must themselves adopt this image, this method of calculation, in order for the capitalist mode of production to work at all. This is what it means to say that Capital per se is the quasi-cause of social production - in contrast to living labor

\footnotetext{
14"Human labor" must here be taken to include the productivity of what Virno (2004), and Hardt and Negri (2001), call "immaterial labor," "affective labor," and "general intellect." Though certain theorists (e.g. Lazzarato 2004) seem to think that such phenomena invalidate Marx's insights about the exploitation of "living labor," they actually conform all too fully to the ways in which productive causal processes are appropriated by, and assimilated to, the quasi-causality of Capital.
} 
as its material cause. Marx says that "the movement of capital is... limitless," because "the circulation of money as capital is an end in itself... the valorization of value takes place only within this constantly renewed movement" $(1992,253)$. In Deleuze and Guattari's terms, Capital as the Body without Organs incessantly "falls back on (se rabat sur) all production, constituting a surface over which the forces and agents of production are distributed, thereby appropriating for itself all surplus production and arrogating to itself both the whole and the parts of the process, which now seem to emanate from it as a quasi cause... the socius as a full body forms a surface where all production is recorded, whereupon the entire process appears to emanate from this recording surface" $(1983,10) .{ }^{15}$

It might seem, at this point, that I have gone far afield from the discussion of Whitehead's notion of God with which I began this chapter. But Whitehead's God, like the Body without Organs, is best understood - in the way first adumbrated by Kant - as the operator of the disjunctive synthesis, in both its limitative and inclusive uses. "We conceive actuality as in essential relation to an unfathomable possibility," Whitehead says (1925/1967, 174). God, like the Body without Organs, figures and embodies this "essential relation." He facilitates the passage - in both directions - between limitless potentiality on the one hand, and the concrete existence, or "givenness" (1929/1978, 43), of actual occasions, on the other. Much like the Body without Organs, God is only a quasi-cause. He does not actually create the universe: for Whitehead, creation happens in the concrescent decisions of all actual occasions, just as, for Deleuze and Guattari, creation is the productive activity of all the desiring machines. But God can be regarded as a sort of adjoining co-creator. In Science and the Modern World, Whitehead suggests that God provides the "antecedent limitation among values" that is the condition of possibility for all creation $(1925 / 1967,178)$. And in Process and Reality, Whitehead

\footnotetext{
${ }^{15}$ Capital is not the material cause of what it produces; but, as that which organizes and conceptualizes the system of production, it emerges retrospectively as the quasi-cause. This is perhaps why we should be suspicious of the current mania for self-organization and emergence. There is nothing inherently liberating about such concepts. For every Deleuzian account of selforganization, like the brilliant one worked out by Brian Massumi (2002), there is also an account, by the likes of Friedrich Hayek (1991) or Kevin Kelly (1994), of the capitalist market as a wondrously self-organizing system. The theology of market self-organization is the postmodern version of Adam Smith's capitalist/Calvinist notion of the Invisible Hand; like its predecessor, this theology simply ignores all questions of exploitation. For Deleuze and Guattari, the problem is how to imagine a form of self-organization that is not exploitative, and that does not just reproduce and expand itself, pushing itself to its limit and then recomposing itself anew at every limit. This is also the problem of how genuine novelty, as imagined by Whitehead and by Deleuze, might be something other than incessant capitalist innovation, "capitalistic fashion-novelty."
} 
says that God both stimulates each occasion's concrescent decisions (the "primordial nature of God"), and registers them (the "consequent nature of God"). In this way, Whitehead's God can well be regarded, like the Body without Organs, as a figure of induction, circulation, and communication. ${ }^{16}$

My aim here is not to identify Whitehead's God with the Body without Organs, but only to suggest that the two concepts are structurally parallel. They both respond to the same necessity: that of conceiving a non-totalizing and open "whole" in which all potentiality may be expressed. A metaphysics of process and becoming cannot do without some principle of unification, lest it drift off into atomized incoherence. But it also cannot allow such a principle to fix it into any sort of finality or closure. ${ }^{17}$ Deleuze and Guattari therefore proclaim that they "believe only in totalities that are peripheral. And if we discover such a totality alongside various separate parts, it is a whole of these particular parts but does not totalize them; it is a unity of all of these particular parts but does not unify them; rather, it is added to them as a new part fabricated separately" $(1983,42)$. The Body without Organs is a "whole" or "unity" that does not subsume, but subsists alongside, the flows and cuts whose permutations it records and attributes to itself. Whitehead's God is also such a peripheral "whole" or "unity." Indeed, "each temporal

\footnotetext{
${ }^{16}$ I will only touch briefly here on the vexed question of the relation between what Whitehead calls the "primordial" and "consequent" natures of God. The primordial nature of God is purely conceptual, as it involves potentiality or virtuality: "viewed as primordial, he is the unlimited conceptual realization of the absolute wealth of potentiality. In this aspect, he is not before all creation, but with all creation" (1929/1978, 343). This is God as "the principle of concretion the principle whereby there is initated a definite outcome from a situation riddled with ambiguity" (345). The consequent nature of God, on the other hand, is physical and actual. It "is derived from the objectification of the world in God... the concrescent creature is objectified in God as a novel element in God's objectification of that actual world" (345). That is to say, the consequent nature of God involves something like the inscription, or recording, of everything that has happened in all actual occasions. The primordial nature of God is an opening towards futurity, the condition of possibility for every becoming. The consequent nature of God is like Bergsonian memory, or "pure recollection": the "being in itself of the past" (Deleuze 1991, 60), or its preservation as past. Very roughly speaking, the primordial nature of God corresponds to the Body without Organs as virtual "full body"; while the consequent nature of God corresponds to the Body without Organs as "recording surface."

${ }^{17}$ This is what differentiates process thought from any form of the dialectic. For Bergson, Whitehead, and Deleuze, and contrary to Hegel $(1977,407)$, "the wounds of the Spirit" can never be made whole; and they always do leave scars behind. The past persists as past, in its entirety: an "objective immortality" that cannot be subsumed or sublated. But this persistence is itself the condition for a radically open future, one that cannot be prefigured or contained by any sort of dialectical movement.
} 
occasion embodies God, and is embodied in God" (Whitehead 1929/1978, 348). But this God only sits alongside the world, rather than actually containing and determining it.

This is evident especially in the way that Whitehead revises Kant. Whitehead's God, like Kant's, is concerned with "possibility in its entirety" (Kant 1996, 564). But where Kant's God encompasses, or grounds, all possible predicates, Whitehead's God merely "envisages" eternal objects (cf. Whitehead 1929/1978, 44). Eternal objects are not quite the same thing as predicates, ${ }^{18}$ and envisagement is a far more modest activity than "thoroughgoing determination." If God "envisages" potentialities, this carries the suggestion that he is merely approaching them from the outside. And indeed, Whitehead's God displays a basic appetition: "an urge towards the future based upon an appetite in the present" (32). God's desire consists in "yearning after concrete fact - no particular facts, but after some actuality" (33). This would be superfluous, and indeed ridiculous, in the case of a Being who was already the principle of a "thoroughgoing determination" of reality. But for Whitehead, it is only possible to conceive of God at all if we conceive of him as an empirical phenomenon, "an actual entity immanent in the actual world" (93). God is "primordial," in the sense that his "aversions and adversions" encompass "the complete conceptual valuation of all eternal objects" - in contrast to all other entities, which just prehend a limited selection of them. But this "primordial nature" must itself be recognized, not as an overarching transcendence, but simply as "an actual efficient fact" (32).

In other words, Whitehead accepts the challenge that Kant throws down to specu-

\footnotetext{
${ }^{18}$ Whitehead defines a "predicate" as a "complex eternal object" that is assigned to some "logical subject," which may be an actual entity or a society of such entities $(1929 / 1978,24)$. This means that predicates are elements of "propositions," or of limited hypotheses concerning matters of fact. "The predicates define a potentiality of relatedness for the subjects" of a proposition (188). The point is that predicates are only a subset of eternal objects. Every actual entity aside from God "entertains," or admits into feeling, particular predicates. But God envisages all eternal objects, indiscriminately. Predication in propositional thought is a kind of limitative use of the disjunctive synthesis; but God's envisagement of eternal objects is not thus limited.

Also, it is only with "the acceptance of the 'substance-quality' concept as expressing the ultimate ontological principle" that potentialities are limited to the status of predicates (157). Once we free ourselves of the 'substance-quality' concept, we can conceive of eternal objects as more than predicates. Whitehead ultimately defines eternal objects as "Pure Potentials for the Specific Determination of Fact"; it is thanks to the "ingression" of these pure potentials into actual entities that "it belongs to the nature of a 'being' that it is a potential for every becoming" (22). This "principle of relativity" corresponds to an inclusive and nonrestrictive use of the disjunctive syllogism.
} 
lative theology: "if the empirically valid law of causality is to lead to the original being, then this being would likewise have to belong to the chain of objects of experience; but in that case this being would itself, like all appearances, be conditioned in turn" $(1996,613)$. Whitehead's God is a special sort of entity, but one that is still conditioned, still part of "the chain of objects of experience." He is transcendent, but only in the way that other entities also are: "the transcendence of God is not peculiar to him. Every actual entity, in virtue of its novelty, transcends its universe, God included" (93-94). God is himself subject to what Whitehead calls the ontological principle: "that actual entities are the only reasons; so that to search for a reason is to search for one or more actual entities" (24). Whitehead's God, through his desires, provides a "reason" for all other actual entities; but these entities, in turn, also provide reasons for him. Any account of "sufficient reason" must include God; but such an account can never be limited just to God.

Where Kant's God directly corresponds to the overarching relational category of "community" (the reciprocal determination of all entities), Whitehead's God is only another member of this community. "The actual world must always mean the community of all actual entities, including the primordial actual entity called 'God' and the temporal actual entities" (1929/1978, 65). God does not determine the relation of community, but is caught up within this relation as one of its terms. Or, to put it in another way, God cannot himself be the principle of the reciprocal determination of entities in the world, because God and the World already reciprocally determine one another, in the larger movement of what Whitehead calls "creativity." This is why Whitehead can posit a series of strange and striking Antinomies in the relationship between God and World. These two terms "stand over against each other," mutually interpenetrating but never coinciding. For "God and the World are the contrasted opposites in terms of which Creativity achieves its supreme task of transforming disjoined multiplicity, with its diversities in opposition, into concrescent unity, with its diversities in contrast" (348).

When Whitehead first introduces the notion of God, in Science and the Modern World, he stresses the limitative use of the disjunctive synthesis. God's role is to impose "an antecedent limitation composed of conditions, particularizations, and standards of value... Some particular how is necessary, and some particularization in the what of matter of fact is necessary" $(1925 / 1967,178)$. This emphasis is continued in Process and Reality. As Principle of Concretion, God stands for the constrictions of "stubborn fact which cannot be evaded" (1929/1978, 43). God is the fatality of the situation in which the wave function has already collapsed. 
The box is opened, and Schrödinger's Cat is discovered once and for all either to be alive or to be dead. A single definitive route has been chosen through the labyrinthine branchings of Borges' Garden of Forking Paths, and the steps can no longer be retraced. This limitative use of the disjunctive synthesis is a consequence of the irreversibility of time. Once the selection has been made, it cannot be reverted to, or altered. The "inevitable ordering of things, conceptually realized in the nature of God," is without appeal, and without justification: "this function of God is analogous to the remorseless working of things in Greek and in Buddhist thought. The initial aim is the best for that impasse. But if the best be bad, then the ruthlessness of God can be personified as Atè, the goddess of mischief. The chaff is burnt" (244). Whitehead's objection to Leibniz comes down to the way that Leibniz seeks to justify this fatality, to insist that God makes a rational selection among possible worlds, and that this selection is ultimately for the best. To the contrary, Whitehead insists that, if "God is the ultimate limitation," then "His existence is the ultimate irrationality. For no reason can be given for just that limitation which it stands in His nature to impose" (1925/1967, 178). God is not just inexorable; he is also arbitrary. ${ }^{19}$

But if God enforces the irreparability of the past, he also guarantees the openness of the future. And in this role, he stands for an inclusive and nonrestrictive use of the disjunctive synthesis. God "embod[ies] a basic completeness of appetition" (Whitehead 1929/1978, 316): that is to say, his "urge towards the future," or "yearning after fact," embraces all potentials (all eternal objects) absolutely indiscriminately. God's "primordial nature" involves "the unconditioned conceptual valuation of the entire multiplicity of eternal objects" (31). This means that Whitehead's God, no less than Schreber's or Klossowski's, envisages a passage through all possible combinations of predicates (or better, of qualities and affects) without regard for their incompatibilities with one another. In this sense, God encom-

\footnotetext{
${ }^{19}$ This is yet another way in which Whitehead remains an heir to Kant's critical revolution, rather than reverting to pre-critical thought. Deleuze lists as one of Kant's great "poetic formulas" the way that "Kant reverses the relationship of the law and the Good." Where traditional metaphysics, from Plato onward, derives all moral laws from the the ideal of the Good, for Kant "it is the Good which depends on the Law, and not vice versa... The Law as empty form in the Critique of Practical Reason corresponds to time as pure form in the Critique of Pure Reason" (Deleuze 1984, x). Whitehead replaces Kant's "empty form" of the Categorical Imperative with God's merely empirical arbitrariness; but he remains Kantian in his refusal to subject this arbitrary "decision" to any pre-existing standard of rationality or Goodness, or to any higher form of justification. "What is metaphysically indeterminate has nevertheless to be categorically determinate. We have come to the limits of rationality" (Whitehead 1925/1967, 178).
} 
passes "the general potentiality of the universe" (46), unconstrained by particular actualizations. And this surplus of potentiality is never exhausted; it "retains its proximate relevance to actual entities for which it is unrealized" (46). That is to say, "the vector prehensions of God's appetition" (316) enter into the experience of every actual occasion. God's envisagement of all eternal objects - including the ones that a given occasion would not otherwise encounter in its environment - is itself an objective datum for every new concrescence.

The presence of God's "conceptual feelings" as "data" for all actual occasions $(1929 / 1978,247)$ is the reason why there is never just mere repetition. In every concrescence, "physical inheritance is essentially accompanied by a conceptual reaction partly conformed to it, and partly introductory of a relevant novel contrast, but always introducing emphasis, valuation, and purpose" (108). God is the source of such a "conceptual reaction" involving "contrast"; he provides the alternatives that allow the entity to make its own "decision." This is why Whitehead proclaims, again and again, that "apart from God, there could be no relevant novelty" (164); that "God is the organ of novelty, aiming at intensification" (67); that, "apart from such orderings" of eternal objects as occur in the primordial nature of God, "novelty would be meaningless, and inconceivable" (40); and that "apart from the intervention of God, there could be nothing new in the world" (247).

God is a force for novelty, precisely because he does not determine the actual course of events. To the contrary, he ensures the indeterminacy of this course, its openness to difference in the future. God does not decide anything; but he offers material for the decisions made by all other entities. Whitehead's God is therefore an anti-entropic force; without him, "the course of creation would be a dead level of ineffectiveness, with all balance and intensity progressively excluded by the cross currents of incompatibility" (247). God renovates the universe by making incompossibles compatible. In case of contradiction or exclusion, he "converts the opposition into a contrast" (348), so that formerly irreconcilable terms become thinkable and realizable together. Whitehead's God may not quite embody the category of community (reciprocal determination) in the way that Kant's does; but at least he widens the scope of such community. God is the reason why mere linear causality (the "causal efficacy" of "physical inheritance") cannot completely determine (although, of course, it very strongly constrains) the course of events. Even more, God is a stimulus for change: in Whitehead's most striking phrase, he is "the goad towards novelty" (88). God provides the "lure for feeling" (189) that seduces an entity into its process of becoming, or that draws it into difference. 
Whitehead's God is the Principle of Concretion, then, in a double sense. Through the limitative use of the disjunctive synthesis, God enforces the narrowing-down of potentials that is a necessary part of any movement of concrete actualization. He embodies the requirement that each actual entity must make a "decision," in order to exhibit a "determinate attitude towards every element in the universe" $(1929 / 1978,45)$. Deleuze would have to say that, for such a God, "disjunctions have the negative value of exclusion" (Deleuze 1990, 297). But at the same time, through the inclusive use of the disjunctive synthesis, Whitehead's God also distributes multiple (and even incompatible) potentials, widening the scope of the actual entity's "decision," and allowing it, or forcing it, to enact "the modification of its initial subjective aim" (Whitehead 1929/1978, 245). This is the God that, according to Deleuze's reading of Whitehead, "becomes Process, a process that at once affirms incompossibilities and passes through them" (Deleuze 1993, 81). In Whitehead's own terms, through God's intervention "the actual includes what (in one sense) is 'not-being' as a positive factor in its own achievement," so that "fact is confronted with alternatives" (Whitehead 1929/1978, 189, repeating $1925 / 1967,176)$. The entity is now able to depart from mere "conformation to pattern," and instead express "novel conceptual feeling," by claiming and proclaiming "its own flash of autonomous individual experience" (1929/1978, 245). All in all, "the creative process is a process of exclusion to the same extent as it is a process of inclusion" (1926/1996,113). Every entity's creative "decision" is an act both of narrowing down (as multiple potentials are congealed into a single actuality), and of opening up (as alternative possibilities are "entertained"); and God is the promoter, or the catalyst, of both of these facets of the process. ${ }^{20}$

\footnotetext{
${ }^{20}$ Tim Clark, in his lucid and powerful discussion of Deleuze's encounter with Whitehead (2002), argues against Deleuze's reading of Whitehead's God as a figure of affirmation and metamorphosis. For Clark, Whitehead's God never performs the disjunctive synthesis in a fully affirmative or Deleuzian manner. Rather, since for Whitehead "restriction and limitation are the conditions of value," Whitehead's God "is still required to enact, or at least to found, disjunctions that are not yet positively synthetic or wholly affirmative" (198). Whitehead never quite reaches the condition of a Deleuzian "chaosmos," because "within Whitehead's system the universe remains, in principle, only semi-open and therefore partially predictable" (202). Deleuze is misreading, therefore, when he attributes his own "total affirmation" of difference to Whitehead, who never fully escapes "the weight of ontotheological tradition bearing down upon him" (205).

I have learned a lot from Clark's discussion; in particular, I am indebted to him for reading Whitehead's notion of God in the light of Deleuze's discussion of the Kantian (and Klossowskian) disjunctive syllogism. And Clark is entirely right to see elements of limitation and exclusion at work in Whitehead's account of God. I differ from Clark in that I see a movement between the exclusive and inclusive uses of the disjunctive synthesis at work in both Whitehead's account of God and Deleuze's account of the Body without Organs - and, indeed, already in Kant's account
} 
To summarize, Whitehead posits, discovers, or constructs the figure of God for reasons that lie deep in his metaphysics. ${ }^{21}$ Like Aristotle, Whitehead is forced to

of God. Though Deleuze tends to describe the opposition between the two uses of the synthesis polemically and absolutely, in practice he slides back and forth between them - because every actualization of the virtual unavoidably involves some sort of limitation, and because the analysis of forms of coding and capture, on the one hand, and of the mobilization of "lines of flight" on the other, necessarily makes reference to the tension between these two uses.

${ }^{21}$ On the technical level of Whitehead's metaphysics, this account of God is needed in order to resolve the difficulties raised by the Category of Conceptual Reversion. Whitehead initially formulates this Category as follows: "There is secondary origination of conceptual feelings with data which are partially identical with, and partially diverse from, the eternal objects forming the data in the first phase of the mental pole. The diversity is a relevant diversity determined by the subjective aim" $(1929 / 1978,26)$. That is to say, an actual occasion is not limited to prehending only those eternal objects that are realized in the empirical data in front of it. Even if everything that it sees is blue, it is also able to imagine red. It is capable of forming feelings, and yearning after potentialities, that are "diverse from" those provided by "the data in the first phase" of experience.

Now, this is a categorical requirement of Whitehead's system, or what Kant would call a necessary "transcendental presupposition": for otherwise novelty would be impossible. Without some notion of "conceptual reversion," an actual entity that prehended only blue-colored data would never be able to posit redness. But it is hard to see how the Category of Conceptual Reversion is consistent, or coherent, with Whitehead's basic ontological principle, which states that "every condition to which the process of becoming conforms in any particular instance has its reason either in the character of some actual entity in the actual world of that concrescence, or in the character of the subject which is in process of concrescence" (24). Where, then, does the imagination of redness come from? Since, by definition, the datum of a novel conceptual prehension is not present in any "actual entity in the actual world of that concrescence," it must arise out of "the character of the subject which is in process of concrescence," which is to say, out of the entity's "subjective aim."

But how does such a previously "unfelt eternal object" (249) ingress into, and alter, an entity's subjective aim in the first place? What enables "the positive conceptual prehension of relevant alternatives" (249)? Traditional idealist metaphysics resolves this problem by appealing to some Platonic principle of recollection: the Idea of red exists in itself, independently of my thinking it; and for that very reason accessible to my thought. Today's cognitive science, following Kant, retains this argument by subjectivizing it: the Idea of red may not exist in and of itself, but it is a necessary product of innate structures of the human mind. But Whitehead is loath to accept this line of reasoning - even though he compares what he calls "eternal objects" to the Platonic forms (44). For any appeal to already-given forms would mean limiting the scope of novelty, by reducing it to mere structural permutations, or variations of a theme.

At first, Whitehead entertains the idea that eternal objects might have the power within themselves to refer to other, related eternal objects: "the determinate definiteness of each actuality is an expression of a selection from these forms. It grades them in a diversity of relevance. This ordering of relevance starts from those forms which are, in the fullest sense, exemplified, and passes through grades of relevance down to those forms which in some faint sense are proximately relevant by reason of contrast with actual fact" (43-44). But ultimately Whitehead rejects this ar- 
move in this direction because "the general character of things requires that there be such an entity" (1925/1967, 173-174). And in contrast to Leibniz, Whitehead seeks to posit the figure of God in such a way that it does not come off as merely "an audacious fudge" $(1929 / 1978,47)$ used in order to resolve metaphysical discomforts. When Whitehead figures God as a process, and as an empirical being rather than a transcendent one, this means that God cannot be cited as an excuse, or invoked as an ultimate fallback explanation. For the point is precisely that God accounts for nothing, and excuses nothing. "No reason can be given for the nature of God; because that nature is the ground of rationality" $(1925 / 1967,178)$. That is to say, the "ground" is itself groundless and non-rational; it is even "the ultimate irrationality" (178). Where Leibniz (and Hegel too, for that matter) invokes God in order to confirm the rationality of the real, Whitehead invokes God precisely in order to acknowledge the all-too-evident absence of any such higher rationality. Whitehead's God helps to make things happen (in his "primordial" nature); and he contemplates and preserves everything that has happened (in his "consequent" nature). But God cannot be used in order to explain or justify anything.

gument, because "the question, how, and in what sense, one unrealized eternal object can be more, or less, proximate to an eternal object in realized ingression - that is to say, in comparison with any other unfelt eternal object - is left unanswered by this Category of Reversion" (249-250). The "grades of relevance" and proximity among eternal objects can only be determined to the extent that these objects can be ordered in a closed and well-defined set. But this is belied by the fact that "nature is never complete," that "it is always passing beyond itself" (289). Whitehead states that "there are no novel eternal objects" (22); but he also requires us to conceive the "whole" of eternal objects as something other than a closed set. (The notion of a whole that is not a closed set is formulated by Deleuze in relation to Bergson: Deleuze 1986, 10-11).

These considerations lead Whitehead to insist that the question of the ingression of previously unrealized eternal objects "can be answered only by reference to some actual entity." In accordance with the ontological principle, there must be some empirical source for the "missing" eternal objects. The "conceptual prehension" of alternative potentialities must have its roots in a prior "physical prehension." God is the actual entity who fulfills this condition - or, whose existence Whitehead infers from the requirement to fulfill this condition. God prehends all eternal objects indiscriminately, and thereby makes them available to any "temporal entity" whatsoever. Through this appeal to God, "the Category of [Conceptual] Reversion is then abolished, and Hume's principle of the derivation of conceptual experience from physical experience remains without any exception" (250).

Whitehead's struggle with this problem, and his initial assertion, and subsequent rejection, of the Category of Conceptual Reversion, is traced in detail by Lewis S. Ford (1984, 211-241 passim). The crucial point is that Whitehead's recourse to God is in fact, odd as this might seem, a way of rejecting transcendent solutions, and embracing instead an immanent one. God is the correlate of Whitehead's “transcendental empiricism," just as the Body without Organs is of Deleuze's. 
In all this, Whitehead reveals himself, once again, to be Kant's inheritor, to a far greater extent than has generally been recognized. In his quest to secularize the notion of God, Whitehead, like Kant, moves from a speculative stance to a "practical" one. Whitehead makes this point explicitly when he says that his own "line of thought" in regard to God "extends Kant's argument. [Kant] saw the necessity for God in the moral order. But with his metaphysics he rejected the argument from the cosmos. The metaphysical doctrine, here expounded, finds the foundations of the world in the aesthetic experience, rather than - as with Kant - in the cognitive and conceptive experience" (1926/1996, 104-105). Kant, of course, tells us that "it is morally necessary to assume the existence of God" $(2002,159)$. We cannot ever prove, or cognitively establish, that God exists; but our moral duty impels us to assume that he does, and to act as if he does. ${ }^{22}$

Whitehead posits God on the basis of "aesthetic experience," rather than morality. To the extent that we make "decisions" - and, for Whitehead, decision "constitutes the very meaning of actuality" $(1929 / 1978,43)$ - we are engaged in a process of selection. We "feel" (or positively prehend) certain data, and "eliminate from feeling" (or negatively prehend) certain others (23). But this process of selection is an aesthetic one. It is felt, rather than thought (or felt before it is thought); and it is freely chosen, rather than being obligatory. The process of selection rests upon aesthetic critera, rather than upon either cognitive or moral ones. These criteria are what Whitehead calls the Categorial Obligations of "Subjective Harmony" and "Subjective Intensity" (27). The "subjective aim" of every actual occasion is first, to harmonize all its data, by making them "compatible for integration" into "one complex fully determinate feeling" (22); and second, to maximize the intensity of this feeling. The goal of every decision is therefore Beauty, defined by Whitehead as "the mutual adaptation of the several factors in an occasion of experience" (1933/1967, 252). As for the intensity with which this "adaptation" is felt, Whitehead simply notes that "an intense experience is an aesthetic fact" (1929/1978, 277).

\footnotetext{
${ }^{22}$ Kant is careful to point out that "this moral necessity is subjective, i.e. a need, and not $o b$ jective, i.e. itself a duty; for there can be no duty whatever to assume the existence of a thing (because doing so concerns only the theoretical use of reason)" $(2002,159)$. It is not even our duty to believe in God; it is only the case that we are pragmatically forced to believe in God - i.e. that we are unable not to believe in God - to the extent that we follow the commands of moral obligation. God cannot even be invoked as the basis of moral obligation; rather, moral obligation itself provides the sole basis for any belief in God. Whitehead follows Kant in the way that he posits God's existence adjunctively, rather than foundationally. But for Whitehead, it is aesthetics, rather than morality, that forces us to assume the existence of God.
} 
These aesthetic decisions are singular in every case; they cannot be determined in advance, or made according to any rule. God is not the source of aesthetic selection for Whitehead, just as he is not the source of moral obligation for Kant. But the fact of aesthetic decision impels Whitehead to posit God, much as the fact of moral obligation forces Kant to assume that God exists. God is not the origin of creativity, then; but he emerges as a factor "which has to be taken account of in every creative phase" (1926/1996, 94). Whitehead's God may be regarded as a sort of baseline. He embodies the maximum of both harmony and intensity; and he provides a Degree Zero, in relation to which all particular harmonies and intensities can be measured. His "basic completeness of appetition" (1929/1978, 316) enters as a contrast into the particular appetitions (desires) of all actual occasions. God is the one being who never makes an aesthetic selection; for he positively prehends, or aesthetically appreciates, everything - rather than singling out certain things in preference to others. This makes him into a sort of ultimate aesthete: "The primordial appetitions which jointly constitute God's purpose are seeking intensity, and not preservation... He, in his primordial nature, is unmoved by love for this particular, or that particular. . In the foundations of his being, God is indifferent alike to preservation and to novelty. He cares not whether an immediate occasion be old or new, so far as concerns derivation from its ancestry. His aim for it is depth of satisfaction as an intermediate step towards the fulfillment of his own being... Thus God's purpose in the creative advance is the evocation of intensities" (1929/1978, 105).

I can't say that I particularly like this God; but then, I don't suppose that Whitehead wants us to. For even as a figure of unlimited affirmation, God remains a singular being, rather than a totalizing or all-embracing one. Whitehead reminds us that "every actual entity, including God, is something individual for its own sake" (88). This means that God too is acting for his own sake - rather than (as most religions and most philosophers have tended to suppose) for ours. In any case, the question of my own like or dislike for God is irrelevant. What matters is the indispensible function that God performs in Whitehead's universe. In practice, God is the "goad towards novelty," even though novelty per se leaves him indifferent. And he stimulates and cultivates intensities, even when such intensities are inimical to our persistence or survival. ${ }^{23}$ In his very restlessness and relentlessness, God figures the way that difference can emerge in an ostensibly deter-

\footnotetext{
${ }^{23}$ As Whitehead dryly says, "God's purpose in the creative advance is the evocation of intensities. The evocation of societies is purely subsidiary to this absolute end" (105). This "evocation of societies" means precisely the self-perpetuation of living organisms such as ourselves.
} 
ministic cosmos, and that Newness can arise out of the recombination of already existing elements. These questions of emergent order, and of innovation through appropriation and citation, are ones that centrally engage us today. Whitehead's most abstruse and abstract metaphysical formulations remain strikingly relevant, not just (as Whitehead himself says) to the "insistent craving... of our immediate actions" (348), but also to the social, political, and ecological concerns of our postmodern world.

\section{References}

Badiou, Alain (2003). Saint Paul: The Foundation of Universalism. Trans. Ray Brassier. Stanford: Stanford University Press.

Bloch, Ernst (1986). The Principle of Hope. Trans. Neville Plaice, Stephen Plaice, Paul Knight. Cambridge: MIT Press.

Carter, Angela (1986). The Infernal Desire Machines of Doctor Hoffman. New York: Penguin.

Clark, Tim (2002). "A Whiteheadian Chaosmos? Process Philosophy from a Deleuzian Perspective". In: Process and Difference: Between Cosmological and Poststructuralist Postmodernisms. Ed. by Katherine Keller and Anne Daniell. Albany: State University of New York Press. 191-207.

Delanda, Manuel (2006). A New Philosophy of Society: Assemblage Theory And Social Complexity. New York: Continuum.

Deleuze, Gilles (1991). Bergsonism. Trans. Hugh Tomlinson, Barbara Habberjam. New York: Zone Books.

- (1986). Cinema 1: The Movement-Image. Trans. Hugh Tomlinson, Barbra Habberjam. Minneapolis: University of MInnesota Press.

- (1989). Cinema 2: The Time-Image. Trans. Hugh Tomlinson, Robert Galeta. Minneapolis: University of Minnesota Press.

- (1994). Difference and Repetition. Trans. Paul Patton. New York: Columbia University Press.

- (1984). Kant's Critical Philosophy. Trans. Hugh Tomlinson, Barbara Habberjam. Minneapolis: University of Minnesota Press.

- (1983). Nietzsche and Philosophy. Trans. Hugh Tomlinson. New York: Columbia University Press.

- (1988). Spinoza: Practical Philosophy. Trans. Robert Hurley. San Francisco: City Lights Books. 
Deleuze, Gilles (1993). The Fold: Leibniz and the Baroque. Trans. Tom Conley. Minneapolis: University of Minnesota Press.

- (1990). The Logic of Sense. Trans. Mark Lester. New York: Columbia University Press.

Deleuze, Gilles, and Felix Guattari (1987). A Thousand Plateaus: Capitalism and Schizophrenia. Trans. Brian Massumi. Minneapolis: University of Minnesota Press.

- (1983). Anti-Oedipus: Capitalism and Schizophrenia. Trans. Robert Hurley, Mark Seem, Helen R. Lane. Minneapolis: University of Minnesota Press.

Deleuze, Gilles, and Claire Parnet (2002). Dialogues. 2nd ed. New York: Columbia University Press.

Ellis, Warren (2003). Planetary: Crossing Worlds. La Jolla: Wildstorm/DC.

Ford, Lewis S. (1984). The Emergence of Whitehead's Metaphysics: 1925-1929. Albany: State University of New York Press.

Hardt, Michael, and Antonio Negri (2001). Empire. Cambridge: Harvard University Press.

Hayek, Friedrich (1991). The Fatal Conceit : The Errors of Socialism. Chicago: University of Chicago Press.

Hegel, G. W. F. (1977). Hegel's Phenomenology of Spirit. Trans. A. V. Miller. New York: Oxford University Press.

Hume, David (1998). Dialogues Concerning Natural Religion. 2nd ed. Indianapolis: Hackett.

Kant, Immanuel (2002). Critique of Practical Reason. Trans. Werner Pluhar. Indianapolis: Hackett.

- (1996). Critique of Pure Reason. Trans. Werner Pluhar. Indianapolis: Hackett.

Kelly, Kevin (1994). Out of Control: The New Biology of Machines, Social Systems, \& the Economic World. New York: Addison-Wesley.

Klossowski, Pierre (1998). Nietzsche and the Vicious Circle. Trans. Daniel Smith. Chicago: University of Chicago Press.

Lazzarato, Maurizio (2004). Les Révolutions du Capitalisme. Paris: Les Empêcheurs de Penser en Rond.

Leibniz, Gottrfried Wilhelm (1973). Philosophical Writings. Ed. by G.H.R. Parkinson. London: Everyman's Library.

Marx, Karl (1992). Capital: A Critique of Political Economy. Vol. 1. Trans. Ben Fowkes. New York: Penguin.

Massumi, Brian (2002). Parables for the Virtual: Movement, Affect, Sensation. Durham: Duke University Press. 
Price, Lucien (2001). Dialogues of Alfred North Whitehead. Boston: David R. Godine.

Sherburne, Donald (1986). "Decentering Whitehead". In: Process Studies 15.2. 83-94.

Stengers, Isabelle (2002). Penser avec Whitehead: une libre et sauvage création de concepts. Paris: Seuil.

- (2005). "Whitehead's Account of the Sixth Day". In: Configurations 13.1. 35-55.

Virno, Paolo (2004). A Grammar of the Multitude. Los Angeles, New York: Semiotext(e).

Whitehead, Alfred North (1933/1967). Adventures of Ideas. New York: The Free Press.

- (1951). "Immortality". In: The Philosophy of Alfred North Whitehead. Ed. by Paul Arthur Schlipp. New York: Tudor Publishing House. 682-700.

- (1929/1978). Process and Reality. New York: The Free Press.

- (1926/1996). Religion in the Making. New York: Fordham University Press.

- (1925/1967). Science and the Modern World. New York: The Free Press.

- (1920/2004). The Concept of Nature. Amherst, New York: Prometheus Books.

Zizek, Slavoj (2003). The Puppet and the Dwarf: The Perverse Core of Christianity. Cambridge: MIT University Press. 